\title{
1-Methylcyclopropene on Fruit Quality of Se-Enriched Grape (Vitis vinifera L.) during Shelf Life Period
}

\author{
Shuaimeng Zhu ${ }^{1,2} \oplus$, Yinli Liang ${ }^{1, *}$, Lan $\mathrm{Mu}^{3}$, Xiaojuan An ${ }^{4}$ and Hongfei Yin ${ }^{1}$ \\ 1 Institute of Soil and Water Conservation, Northwest A\&F University, Shaanxi Yangling 712100, China; \\ zhusm@hpu.edu.cn (S.Z.); m15666026570@163.com (H.Y.) \\ 2 School of Surveying and Land Information Engineering, Henan Polytechnic University, \\ Jiaozuo 454150, China \\ 3 Northwest Institute of Historical Environment and Socio-Economic Development, \\ Shaanxi Normal University, Xi'an 710062, China; mulan820706@snnu.edu.cn \\ 4 College of Bioengineering and Biotechnology, Tianshui Normal University, Tianshui 741000, China; \\ anxiaojuan0301@163.com \\ * Correspondence: liangyl@ms.iswc.ac.cn; Tel.: +86-1399-281-2391
}

Received: 2 August 2020; Accepted: 31 August 2020; Published: 17 September 2020

check for updates

\begin{abstract}
Selenium (Se) deficiency in humans could be improved by biofortification of food with selenium, 1-Methylcyclopropene (1-MCP) treatment is beneficial for the non-sulfur storage of fresh fruit. This study investigated fruit quality of table grape (Hutai No.8) with foliar Se fertilizer at maturity, and fruit quality changes of table grape during shelf life stages that caused by postharvest 1-MCP treatment in 2016 and 2017. The results showed that foliar Se fertilizer application significantly increased Se content in grape berries at maturity, and the raised rate were $43.09 \%$ and $33.24 \%$ compared to that of control in 2016 and 2017 respectively, meanwhile it increased the nutritional components in grape berries, including soluble proteins, soluble sugars, Vitamin C, total soluble solids, proanthocyanidin content and so on, and decreased the titratable acidity content. During shelf life stages, 1-MCP application decreased the decay number of grapes, and SE + 1-MCP treatment had the most excellent fruit quality among all treatments in two consecutive vintages. In conclusion, Se fertilizer application could increase Se content in grape berries, also improved the fruit nutritional and health care values at maturity. 1-MCP application could delay the process of ripening and senescence for Se-enriched grape and maintaining the postharvest quality of table grape during shelf life stages, it allows us to market the fruit at a more advanced ripening stage without quality loss.
\end{abstract}

Keywords: 1-MCP; Se fertilizer; Hutai No.8; table grape; postharvest

\section{Introduction}

Grape (Vitis vinifera L.) is the head among the four largest fruits (apples, grapes, oranges and bananas) in the world, with abundant nutrition (such as soluble sugars, proteins, nutriment elements, and so on) and health care values (such as vitamins, resveratrol and proanthocyanidin) that are essential to human health [1,2]. With deeper understanding of Se on human nutrition, more and more Se-enriched grape comes into people's horizon, it causes significant attention from all walks of people.

Selenium (Se) is an essential microelement in human nutrition [3]. Agronomic biofortification with Se-enriched fertilizers is an effective means to increase Se intake in dietary by humans $[4,5]$. Now, spraying Se fertilizer is an effective way of developing Se-enriched fruit, and a new practice for high quality production in fruit cultivation. Using organic Se sources in plants can regulate Se nutrition from the source and prevent related Se deficiency diseases; also, it is a safe, inexpensive and feasible 
way to absorb appropriate Se nutrition from natural foods through the transformation of the food chain [6]. During the plant growth periods, foliar Se fertilizer to increase the Se content in grapes and thereby improve fruit nutritional quality, had become a standard practice [7]. Because of the increasing fruit volume and higher fruit moisture content, phenomenon of decay, threshing, stems browning, and so on happened more easily during the marketing process, then greatly reduced the edible quality and commodity value of table grape [8]. However, the postharvest physiology and fresh-keeping technology on Se-enriched grape had not yet been reported in detailed. Exploring fresh-keeping technology of Se-enriched grape will be an important factor that determined the commodity of Se-enriched fruit, and accordingly, extending the supply of Se-enriched grapes in commercial market. 1-Methylcyclopropene (1-MCP) is an effective ethylene action inhibitor, that could remove the effect of endogenous and exogenous ethylene on fruit quality in a certain period of shelf life stage $[9,10]$. The 1-MCP inhibits ethylene production was considered that 1-MCP was combined with ethylene receptor, thereby cut off the combination of ethylene and ethylene receptor [11,12]. It had been widely used to maintain fruit quality during storage, and to extend the shelf life of fruits and vegetables, because it was effective at very low concentrations with non-toxicity and no residue [13]. Some studies indicated that using 1-MCP in fruits slowed down the maturation process and ethylene production in apple fruit [14-16], melon [17], banana [18], kiwifruit, mango, persimmon [19], and pineapple [20]. In brief, 1-MCP could decrease respiration and ethylene production rates, softening and color change, moreover, could extend the shelf life of fresh-cut fruits stored under refrigeration. In addition, it was mainly applied to delay ripening and prolong shelf life storage [21], however, different types of fruit have different effects of 1-MCP.

Due to aforementioned, exogenous Se fertilizer is used to adjust fruit quality characteristics, then produced the high quality Se-enriched grapes. In addition, impact on fruit quality during the shelf life period of 1-MCP will certainly become the focus of attention. This study conducted foliar Se fertilizer during growth periods and 1-MCP application at shelf life period on Hutai No.8 variety. The objective was to (1) examine the effect of foliar Se fertilizer on quality of table grape at maturity; (2) evaluate fruit quality changes under 1-MCP treatments during shelf life periods, furthermore, providing scientific guidance for the cultivation and storage of Se-enriched grape.

\section{Materials and Methods}

\subsection{Experiment Design}

Experiment site was located in Institute of Soil and Water Conservation, Northwest A\&F University, Yangling $\left(34^{\circ} 12^{\prime}-34^{\circ} 20^{\prime} \mathrm{N} ; 108^{\circ}-108^{\circ} 7^{\prime} \mathrm{E}\right.$, elevation $\left.560 \mathrm{~m}\right)$, Shaanxi, China, and was proceed in greenhouse from February to September in 2016 and 2017. The annual average temperature was $12.9{ }^{\circ} \mathrm{C}$, and the annual average precipitation was about $635 \mathrm{~mm}$. Dark loessial soil was formed by $46.4 \%$ sand, $37.0 \%$ silt and $16.6 \%$ clay on average, soil $\mathrm{pH}$ was 7.9 ; soil electrical conductivity was $0.7 \mathrm{mS} / \mathrm{cm}$; soil water holding capacity was $24 \%$ (mass basis); soil bulk density $(0-30 \mathrm{~cm})$ was $1.2 \mathrm{~g} / \mathrm{cm}^{3}$; soil nutrients were mainly $14.66 \mathrm{~g} / \mathrm{kg}$ organic matter; $0.82 \mathrm{~g} / \mathrm{kg}$ total $\mathrm{N}$; total $0.99 \mathrm{~g} / \mathrm{kg} \mathrm{P} \mathrm{O}_{5} ; 28.75 \mathrm{mg} / \mathrm{kg}$ available $\mathrm{N}$ ( $1 \mathrm{~mol} / \mathrm{L} \mathrm{NaOH}$ hydrolysis); $30.46 \mathrm{mg} / \mathrm{kg}$ available $\mathrm{P}(0.5 \mathrm{~mol} / \mathrm{L} \mathrm{NaHCO}$ ); $153.68 \mathrm{mg} / \mathrm{kg}$ available $\mathrm{K}\left(1 \mathrm{~mol} / \mathrm{L}\right.$ neutral $\left.\mathrm{NH}_{4} \mathrm{OAc}\right)$; and $59 \mathrm{ug} / \mathrm{kg}$ Se content in soil.

Hutai No.8 variety ( $\mathrm{Xi}^{\prime}$ an institute of grapes) was used in this experiment, which is European and America hybrid specie, which had the characteristics of early maturity, excellent quality, high yield, strong disease resistance, low temperature resistance, storage and transportation resistance, no dropping, easy management and so on, and it is the main cultivar of fresh grape in Xi'an in recent years. Also, it is at the international advanced level in both yield and quality, especially the advantage of not easy to grain, which solves the problem of international grape storage and transportation. In this study, it was grown using stem cutting (no rootstock) in greenhouse in 2012. In plant growth periods, including CK (control, pure water) and SE treatments (Se fertilizer, it was a foliar fertilizer with amino acid-chelated Se-enriched of organic Se $\geq 60 \mathrm{~g} / \mathrm{L}$, come from Shaanxi Yangling Macao bond biological 
science Co., LTD. located in Yangling, Shaanxi Province). Spraying Se fertilizer with $120 \mathrm{~g} / \mathrm{L}$ (according to preliminary experimental results) on leaves of SE treatments during young fruit to fruit swelling period after 17:00-18:00 on 17 May, 28 May and 8 June 2016 respectively. At the same time, pure water was sprayed on CK treatments, and repeat the same operation in 2017.

There were eight plots, and each plot measured $6.5 \mathrm{~m}$ by $3.5 \mathrm{~m}$, and a randomized block design with four replications was adopted, sixteen vines of Hutai No. 8 that were stem cutting in 2012 were grafted in a plot in 2016. The local farm management strategy was applied in plantation, such as organic fertilizer (organic matter content $\geq 45 \%$, total nutrient content of $\mathrm{N}^{-} \mathrm{P}_{2} \mathrm{O}_{5}-\mathrm{K}_{2} \mathrm{O} \geq 5 \%$ ) application following $180 \mathrm{~g}$ per tree after pruning in 2015, $40 \mathrm{~g} \mathrm{~K}$ fertilizer per tree and $20 \mathrm{~g}$ urea per tree was application on 12 May 2016. A little irrigation was carried out after each fertilization. In addition, when soil water content under $60 \%$ of field capacity, that was determined by TDR (time domain reflectometry) in germination, fruit swelling, berries coloring periods, carried out three supplementary irrigation with $90 \%$ of field capacity to fill up respectively. Each vine reserved 7-9 fruit clusters and keep about 60 fruit per cluster when fruit thinning, and all the managements were same in 2017.

Grape berries were harvested on 2 September 2016 and 17 August 2017 respectively. Then, they were transported to laboratory for fruit quality determination immediately, and the rest were stored under room temperature for the next shelf life experiments. Eight hours later, half of grape berries were treated with 1-MCP (the powder with 3.3\% of active ingredient, Agrofresh Inc. Philadelphia, PA, USA), and the rest were as control (CK). 1-MCP treatments ( $1 \mathrm{uL} \mathrm{L}^{-1}$, according to the manufacturer's recommendation) were performed in an air regulate case sealed immediately and fumigation $24 \mathrm{~h}$ under the room temperature $\left(20 \pm 1^{\circ} \mathrm{C}\right)$, non-treated grapes were also introduced in the regulate case without active product at their corresponding temperature. After venting, all of samples were stored on a shelf under the room temperature about $20 \pm 1^{\circ} \mathrm{C}$ (simulated shelf life). Fruit quality indexes were measured once a week, combined the determination results of each index to end the determination of shelf life. All treatments in 2016 and 2017 were in Table 1.

Table 1. The treatments in 2016 and 2017.

\begin{tabular}{cc}
\hline Preharvest Treatments & Postharvest Treatments \\
\hline \multirow{2}{*}{ CK } & $\mathrm{CK}+\mathrm{CK}$ \\
\multirow{2}{*}{$\mathrm{SE}$} & $\mathrm{CK}+1-\mathrm{MCP}$ \\
& $\mathrm{SE}+\mathrm{CK}$ \\
$\mathrm{SE}+1-\mathrm{MCP}$
\end{tabular}

Notes: CK—control treatments; SE—selenium fertilizer treatments; 1-MCP-1-Methylcyclopropene treatments.

\subsection{Measurement Methods of Samples}

\subsubsection{Sampling of Grape Berries}

At harvest, five fruit clusters for each replicate were gathered randomly, and 20 fruit of each cluster were selected randomly were used to characterize fruit quality. Berry samples were rinsed three times with distilled water, and dry out surface water, then homogenate with a juicer, transfer to a glass-bottle in $4{ }^{\circ} \mathrm{C}$ refrigerator for the determination of fruit quality. In addition, during the shelf life periods, four dynamic samplings were interval of a week in 2016 and 2017, respectively. Similarly, five fruit clusters for each replicate were gathered randomly, and 20 fruit of each cluster were selected randomly that used to characterize fruit quality.

\subsubsection{Grape Physical Property}

At each evaluation date, fruit decay was calculated by recording the number of five fruit clusters for each replication, the average of the replications was taken for fruit decay in each treatment. 


\subsubsection{Grape Chemical Composition}

All chemical preparations and dilutions used deionized water, and all reagents were analytically pure reagents.

The total Se concentration was determined by the method similar to Premarathna and Toaldo [2,22]. Homogenate sample was digested by a closed vessel microwave procedure (CEM, Matthews, NC, USA) with a three-stage time program: $5 \mathrm{~min}$ at $300 \mathrm{~W}$, then $10 \mathrm{~min}$ at $500 \mathrm{~W}$, and $25 \mathrm{~min}$ at $800 \mathrm{~W}$. Weighed approximately $2.5 \mathrm{~g}$ of finely homogenate sample into a Teflon digestion vessel, then added $10 \mathrm{~mL}$ of concentrate $\mathrm{HNO}_{3}$ and $2 \mathrm{~mL} \mathrm{H}_{2} \mathrm{O}_{2}$. After the solution of microwave digestion was about $1 \mathrm{~mL}$, the vessel was allowed to cool at normal temperature, then added deionized water to $10 \mathrm{~mL}$ (Milli-Q, Millipore, Bedford, MA, USA). Analyzed the total Se concentrations of digest solution through inductively coupled plasma-mass spectrometry (ICP-MS) (820-MS, Varian, Palo Alto, CA, USA) was by.

Total soluble solids (TSS) was determined by an ATAGO PR-101 digital refractometer (ATC-1 Atago, Tokyo, Japan) [23].

Titratable acidities (TA) by titration with $0.1 \mathrm{~N} \mathrm{NaOH}$ [23]. Approximately weight homogenate sample $5 \mathrm{~g}$ into a big glass tube, then add distilled water $20 \mathrm{~mL}$, extract in $80^{\circ} \mathrm{C}$ constant water bath for $30 \mathrm{~min}$, the extracting solution was filtered and dilution, then $25 \mathrm{~mL}$ of extracting solution was added phenolphthalein 2-3 drops, titrate with $0.1 \mathrm{~N} \mathrm{NaOH}$ and record the dosage.

Phenol-sulfuric acid method was used to measure total soluble sugars [23]. Approximately weight homogenate sample $0.3 \mathrm{~g}$ into a glass tube, then add distilled water $5 \mathrm{~mL}$, extract in a boiling water bath for $1 \mathrm{~h}$, the extracting solution was filtered and dilution, then $0.1 \mathrm{~mL}$ of extracting solution was added distilled water, phenol and concentrated sulfuric for reflection $30 \mathrm{~min}$, and analysis of soluble sugar content with a spectrophotometer (Bibby Jenway 6305, Stone, UK) at $485 \mathrm{~nm}$.

Vitamin C (Vc) was determined by molybdenum blue colorimetric method [24]. Approximately weight homogenate sample $3 \mathrm{~g}$ into a centrifuge tube, then add oxalic acid-EDTA mixed liquor $5 \mathrm{~mL}$, centrifuged for $10 \mathrm{~min}$ at $3000 \mathrm{r}$, then shake well and keep warm in the water bath for $15 \mathrm{~min}$, constant volume to $25 \mathrm{~mL}$, the supernatant was used for analysis of $\mathrm{Vc}$ content with a spectrophotometer (Bibby Jenway 6305, Stone, UK) at $760 \mathrm{~nm}$.

Soluble proteins content was measured as follows: put homogenate sample about $2 \mathrm{~g}$ and $6 \mathrm{~mL}$ distilled water into a $10 \mathrm{~mL}$ centrifuge tube, stand for $30 \mathrm{~min}$, then centrifuged. Retained supernatant was used for analysis of soluble proteins by a method of coomassie brilliant blue G-250 [25].

Proanthocyanidin (OPC) content was measured similar to original Porter [26] method: approximately weight homogenate sample $2 \mathrm{~g}$ into a centrifuge tube, then add absolute ethyl alcohol to $10 \mathrm{~mL}$, stand for $30 \mathrm{~min}$. The supernatant was used for analysis of OPC content with a spectrophotometer (Bibby Jenway 6305, Stone, UK) at $525 \mathrm{~nm}$ by a method of molysite catalytic colorimetry.

Resveratrol (RES) content was determined by potassium permanganate fading spectrophotometry similar to Jiang et al. [27]: put homogenate sample $3 \mathrm{~g}$ into a centrifuge tube, and add absolute ethyl alcohol to $10 \mathrm{~mL}$, ultrasonic extraction $30 \mathrm{~min}$, then centrifuged at $5000 \times \mathrm{g}$ for $15 \mathrm{~min}$, retained supernatant was used for analysis RES content by a spectrophotometer (Bibby Jenway 6305, Stone, UK) at $525 \mathrm{~nm}$.

\subsection{Statistical Analysis}

SPSS 20.0 (SPSS Inc., Chicago, IL, USA) were used for statistical analysis of data. Statistically significant differences $(p<0.05)$ from different treatments of postharvest data were revealed after one-way analysis of variance (ANOVA), and multiple comparison followed by Duncan's multiple range test. In addition, a two-factor analysis of variance was performed between Se fertilizer and 1-MCP of fruit quality in 2016. The data of maturity period were compared by independent sample $\mathrm{T}$ test $(p<0.05)$. Graphs were plotted with SigmaPlot 12.5 (Systat Software, San Jose, CA, USA). 


\section{Results}

\subsection{Se Content in Grape Berries}

Foliar Se fertilizer application increased Se content of grape berries at the maturity harvest time in both 2016 and 2017, and Se content in grape berries had significant difference of between SE treatments and CK treatments $(p<0.05)$ (Figure 1). Se content in grape berries was $25.75 \mathrm{ug} / \mathrm{kg}$ and $27.59 \mathrm{ug} / \mathrm{kg}$ respectively under SE treated in 2016 and 2017, meanwhile, the raised rate of Se content was 43.09\% and 33.24\% compared to that of CK in 2016 and 2017, it meets the standard of Se-enriched fruit (20-100 ug/kg).

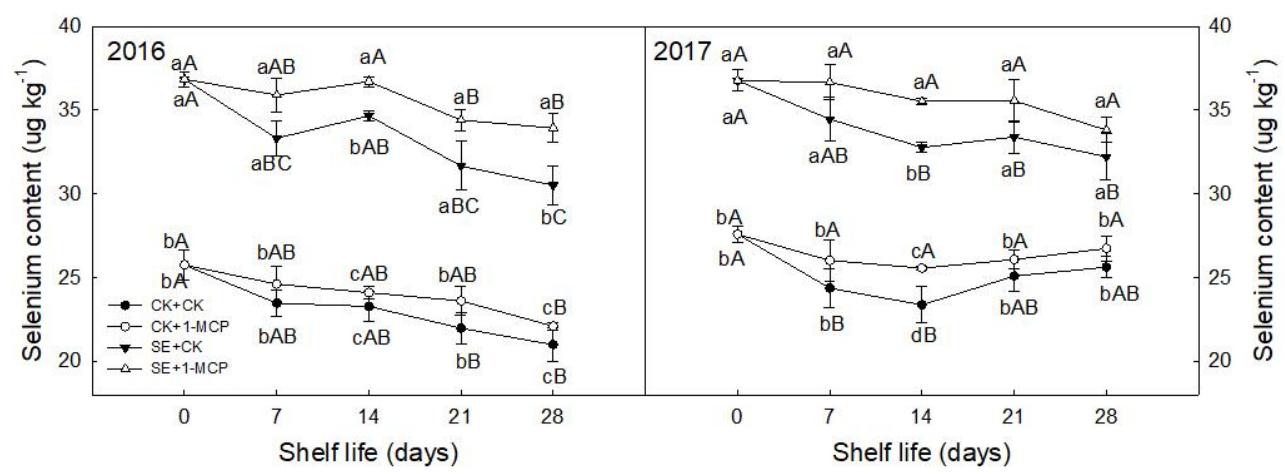

Figure 1. Dynamic changes of Se content in grape berries during shelf life period. Notes: $\mathrm{CK}$ - control treatments; SE-Se fertilizer treatments; 1-MCP-1-Methylcyclopropene treatments. Different lower-case letters on the polyline show significant differences $(p<0.05)$ between different treatments. Different capital letters on the polyline show significant differences $(p<0.05)$ between different shelf life (days).

\subsection{Fruit Quality of Grape Berries at Maturity}

Foliar Se fertilizer significantly increased the soluble sugars, soluble proteins, Vc, TSS and OPC content in grape berries $(p<0.05)$ during two consecutive vintages in 2016 and 2017. However, Soluble sugar is higher in 2016 and less in 2017 either CK or spraying Se fertilizer, which might cause by tree age vigor and the weather factor, because the average rainfall $(850 \mathrm{~mm})$ and the average temperature $\left(20^{\circ} \mathrm{C}\right)$ in 2017 was significantly higher than that in $2016\left(1050 \mathrm{~mm}, 18^{\circ} \mathrm{C}\right)$ during the stage of grape growth, which directedly affected the growth of fruit trees, especially the accumulation of soluble sugar. Similarly, the soluble solid and resveratrol content was high in 2016 and less in 2017 (Table 2).

Table 2. Fruit quality attributes between CK and SE treatments at maturity.

\begin{tabular}{ccccc}
\hline \multirow{2}{*}{ Fruit Quality Attributes } & \multicolumn{2}{c}{2016} & \multicolumn{2}{c}{2017} \\
& CK & SE & CK & SE \\
\hline Soluble sugars $(\mathrm{g} / \mathrm{kg})$ & 160.88 & $174.20^{*}$ & 125.03 & $141.76^{*}$ \\
Soluble proteins $(\mathrm{g} / \mathrm{kg})$ & 1.37 & $1.68^{*}$ & 1.37 & $1.58^{*}$ \\
Vitamin C $(\mathrm{g} / \mathrm{kg})$ & 0.11 & $0.12^{*}$ & 0.10 & $0.12^{*}$ \\
Total soluble solids $(\%)$ & 19.27 & $20.60^{*}$ & 18.97 & $19.97^{*}$ \\
Titratable acidity $(\mathrm{g} / \mathrm{kg})$ & $0.38^{*}$ & 0.33 & $0.44^{*}$ & 0.41 \\
Resveratrol $(\mathrm{mg} / \mathrm{kg})$ & $0.24 \mathrm{~ns}$ & $0.25 \mathrm{~ns}$ & $0.23 \mathrm{~ns}$ & $0.23 \mathrm{~ns}$ \\
Proanthocyanidin $(\mathrm{g} / \mathrm{kg})$ & 4.27 & $6.95^{*}$ & 5.73 & $10.70^{*}$ \\
\hline
\end{tabular}

Note: $\mathrm{CK}$-control treatments; SE—-selenium fertilizer treatments. * show significant difference between CK and SE groups $(p<0.05)$; ns show no significant difference between CK and SE treatments $(p>0.05)$.

In addition, RES content of grape berries under SE treatments was higher than that of CK, but it had no significant difference between $\mathrm{CK}$ and SE groups $(p>0.05)$. Compared to CK group, the titratable acidity content in grape berries under SE treatments was decreased significantly $(p<0.05)$. 


\subsection{The Dynamic Changes of Fruit Quality during Postharvest Period}

\subsubsection{The Decay Number of Grapes during Shelf Life Period}

During two consecutive postharvest stage in 2016 and 2017, whether CK or SE treatments, the decay number of grapes with 1-MCP application were nearly lower than that of non 1-MCP in the process of dynamic measurement (Figure 2). In short, the total decay number of grapes was the highest under SE + CK, followed by CK + CK, while CK + 1-MCP had the least total decay number of grapes. In addition, for the non 1-MCP treated, the total decay number of grapes under Se fertilizer treated was higher than CK group during shelf life stages. Therefore, even if Se fertilizer increased the decay number of grapes during shelf life stages, 1-MCP application of postharvest stage could decrease the total decay number of grapes for both CK and SE treatments in growth periods in both 2016 and 2017.

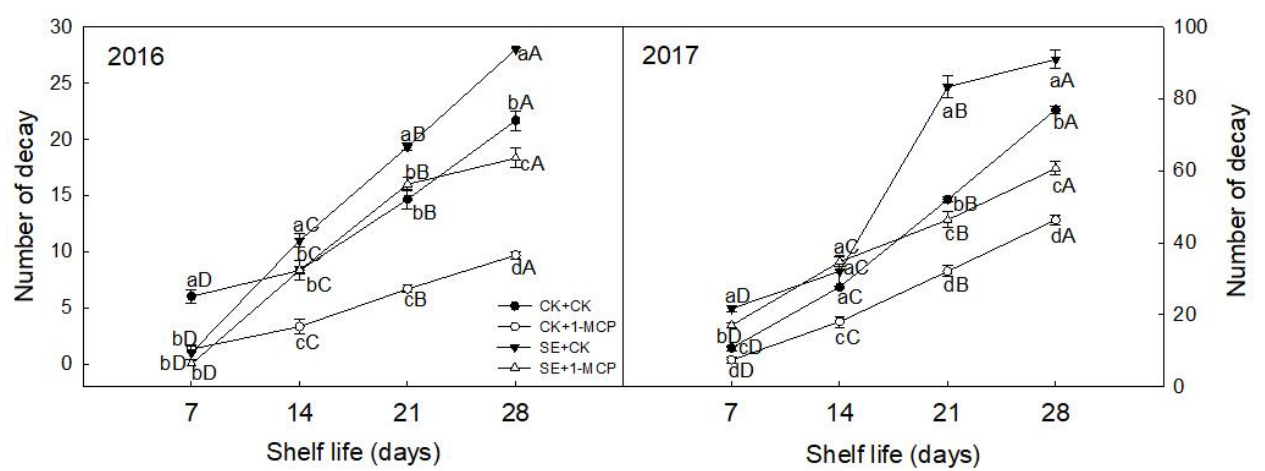

Figure 2. The decay number of grapes during shelf life period. Notes: CK—control treatments; SE-Se fertilizer treatments; 1-MCP-1-Methylcyclopropene treatments. Different lower-case letters on the polyline show significant differences $(p<0.05)$ between different treatments. Different capital letters on the polyline show significant differences $(p<0.05)$ between different shelf life (days).

\subsubsection{Dynamic Changes in Se Content of Grape Berries}

During the whole shelf life periods in 2016 and 2017, Se content of grape berries were decreased constantly for all treatments as time goes on (Figure 1). The decrease of Se content under CK + CK and SE + CK were more obvious at the first week of shelf life-time (2 to 9 September 2016 and 17 to 25 August 2017), the subsequent stages were reduced in waves. Either CK or SE treatments of growth periods, Se content in grape berries that with 1-MCP application was higher compared to the corresponding CK treatments, and it decreased more slowly. Meanwhile, for CK + 1-MCP and SE + 1-MCP treatments in 2017, Se content among five dynamic determinations had no significant difference $(p>0.05)$. In addition, Se content of grape berries under SE treatments (SE + CK/1-MCP) was higher compared to $C K$ treatments significantly $(\mathrm{CK}+\mathrm{CK} / 1-\mathrm{MCP})$ during the whole shelf life periods $(p<0.05)$.

\subsubsection{Dynamic Changes of TSS and Titratable Acidity}

Patterns of change in TSS content were similar between CK and SE treatments in 2016 and 2017, and it showed that TSS content increased first and then decreased (Figure 3). TSS content under CK treatments increased and peaked before decreasing on 16 September 2016 and 1 September 2017 respectively, while TSS content of SE treatments reached its highest value at the first week during postharvest periods except for that of SE $+1-\mathrm{MCP}$ on 9 September 2016. TSS content under CK + CK treatments had significant difference among the five dynamic determinations during the whole shelf life periods in 2016 and $2017(p<0.05)$, hence, it showed that the dynamic changes for TSS content of grape berries under CK + CK treatments performed the most dramatic. Whether CK or SE in the early shelf life stage, the content of TSS in grape berries that treated by 1-MCP were lower than non 1-MCP treatment, while in later shelf life stage, the TSS content with 1-MCP application were higher than non 
1-MCP treated. TSS content of grape berries had significant difference between CK/SE $+\mathrm{CK}$ treatments and $\mathrm{CK} / \mathrm{SE}+1-\mathrm{MCP}$ treatments during the whole shelf life periods $(p<0.05)$.

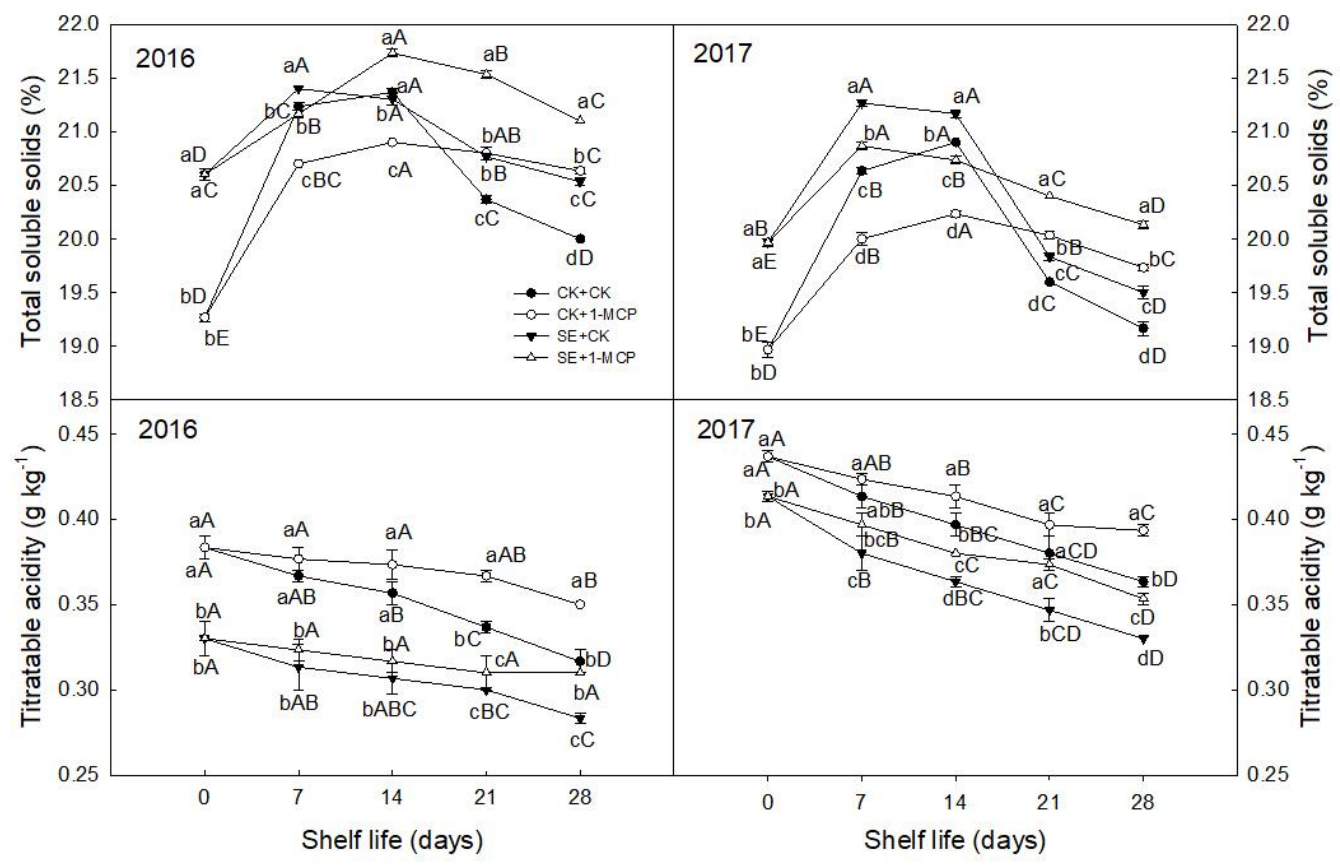

Figure 3. Dynamic changes of titratable acidity and total soluble solids during shelf life period. Notes: $\mathrm{CK}$ - control treatments; SE-Se fertilizer treatments; 1-MCP-1-methylcyclopropene treatments; TSS, total soluble solids. Different lower-case letters on the polyline show significant differences $(p<0.05)$ between different treatments. Different capital letters on the polyline show significant differences $(p<0.05)$ between different shelf life (days).

During the whole shelf life periods in 2016 and 2017, titratable acidity content in grape berries were decreased constantly for all treatments as time goes on. The titratable acidity content was always the highest under CK + 1-MCP treatments, while it always had the lowest titratable acidity content under SE + CK treatments in 2016 and 2017. Either CK or SE treatments of growth periods, the titratable acidity content in grape berries of 1-MCP application was higher compared to that of non 1-MCP treatments, so it showed that 1-MCP application slowed down the decrease of titratable acidity in grape berries, and it maintained the higher titratable acidity content in grape berries during shelf life stage.

\subsubsection{Dynamic Changes in Soluble Sugars and Vc}

Dynamic changes in soluble sugars content of grape berries were similar to the pattern of TSS in both 2016 and 2017, which increased first, and then decreased with the time goes on (Figure 4). The soluble sugars in grape berries under all treatments reached a peak at the second week in 2017 (1 September 2017). Similarly, it reached the peak under CK/SE + 1-MCP treatments at the second week in 2016 (16 September 2016), while it reached the peak under CK/SE + CK at the first week in 2016 (9 September 2016), then decreased quickly during shelf life stages. Whether CK or SE in the early shelf life stages, the content of soluble sugars in grape berries that with 1-MCP treated were lower than non 1-MCP treated, while in the later shelf life stages, the soluble sugars content with 1-MCP application were higher than non 1-MCP treated. So, changes of soluble sugar content in grape berries under 1-MCP treatments was slower than non 1-MCP treated during the whole shelf life stages in 2016 and 2017. 


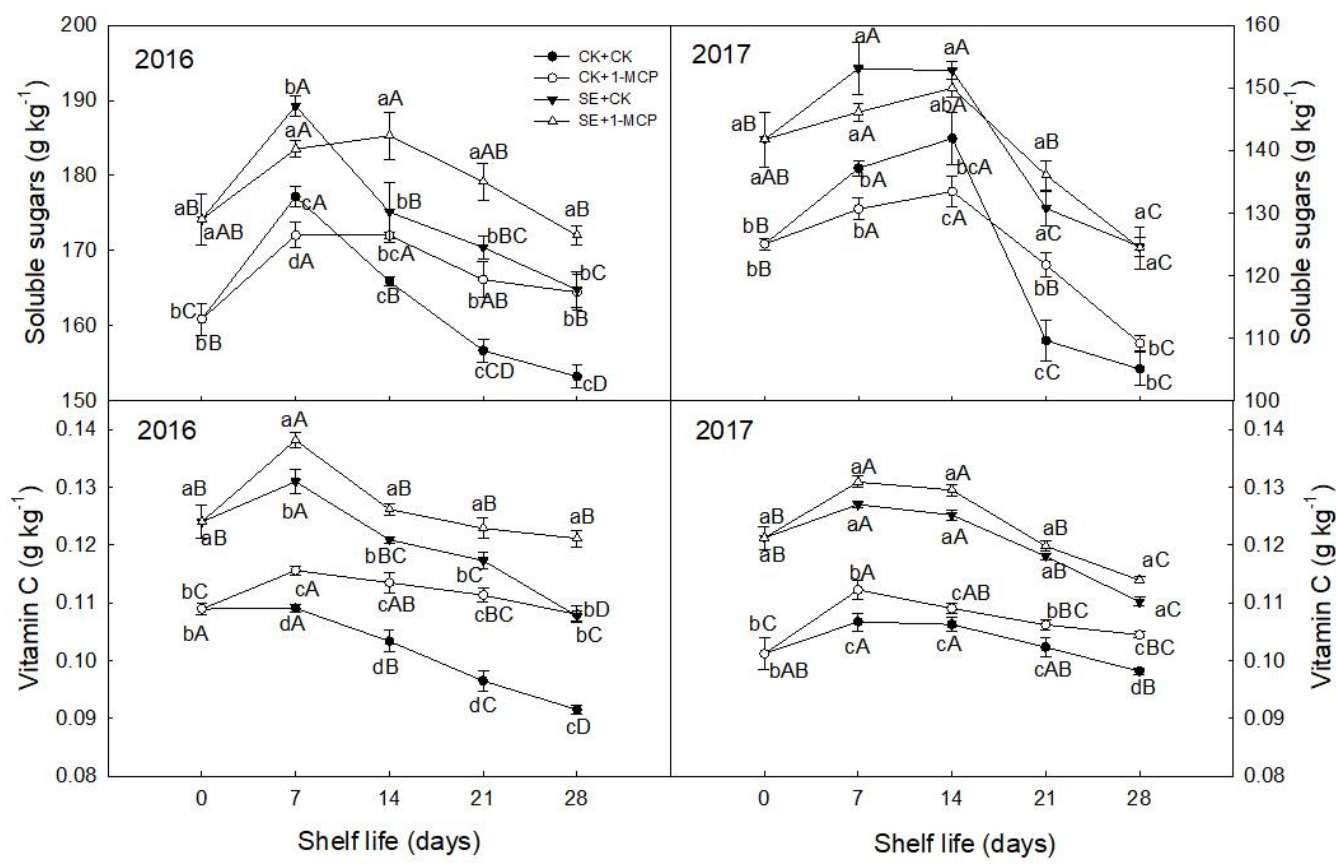

Figure 4. Dynamic changes in soluble sugars and vitamin $C$ during shelf life period. Notes: $C K-c o n t r o l$ treatments; SE-Se fertilizer treatments; 1-MCP-1-methylcyclopropene treatments; Vc, vitamin C. Different lower-case letters on the polyline show significant differences $(p<0.05)$ between different treatments. Different capital letters on the polyline show significant differences $(p<0.05)$ between different shelf life (days).

The content of Vc in grape berries increased and peaked on the first week (9 September 2016 and 25 August 2017) in both 2016 and 2017, then decreasing with time. Vc content of grape berries under SE treated were always higher than CK significantly $(p<0.05)$, except for the last determination on 28 September 2016. In addition, either CK or SE treatments, the Vc content in grape berries under 1-MCP treatments was higher than that of non 1-MCP, and $\mathrm{Vc}$ content had a significant difference between $\mathrm{CK}$ and 1-MCP treated during shelf life period $(p<0.05)$.

\subsubsection{Dynamic Changes of RES and OPC}

As time goes on, changes of RES content in grape berries were fluctuated for all treatments in both 2016 and 2017 (Figure 5). Either CK or SE treatments, RES content in grape berries under 1-MCP treatments was higher than non 1-MCP treatment, and RES content had significant difference between $\mathrm{CK} / \mathrm{SE}+\mathrm{CK}$ and CK/SE + 1-MCP treated at the first- and second-week during shelf life stages $(p<0.05)$. Therefore, in a certain extent, 1-MCP had inhibitory effect on the change of RES content in grape berries during shelf life stage, and it maintained relatively high RES content in grape berries within a period of shelf life stages.

During the whole shelf life periods in 2016 and 2017, OPC content in grape berries decreased constantly for all treatments as time goes on, and the OPC content in grape berries under SE + CK/1-MCP treated was higher than $\mathrm{CK}+\mathrm{CK} / 1-\mathrm{MCP}$ significantly among the five dynamic determinations $(p<0.05)$. In addition, either $\mathrm{CK}$ or SE treatments, the OPC content in grape berries with 1-MCP application was also higher compared to that of non 1-MCP treated. OPC content of grape berries under SE + 1-MCP was always the highest, and it was the lowest under CK + CK. 


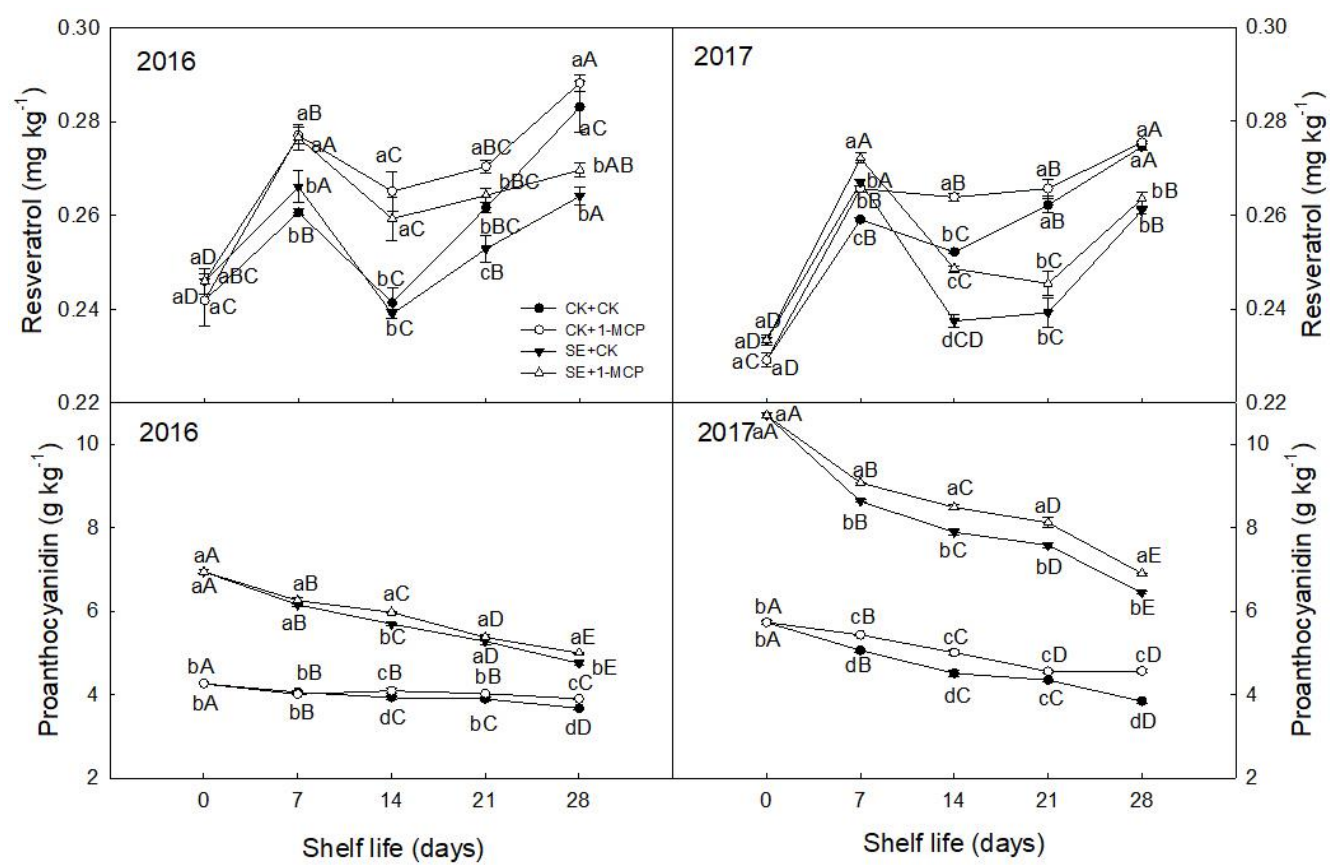

Figure 5. Dynamic changes of resveratrol and proanthocyanidin during shelf life period. Notes: $\mathrm{CK}$ - control treatments; SE-Se fertilizer treatments; 1-MCP-1-methylcyclopropene treatments; RES - resveratrol; OPC - proanthocyanidin. Different lower-case letters on the polyline show significant differences $(p<0.05)$ between different treatments. Different capital letters on the polyline show significant differences $(p<0.05)$ between different shelf life (days).

3.3.6. The Two-Factor Interaction Analysis between Se Fertilizer and 1-MCP of Fruit Quality in 2016

The results of two-factor analysis showed that Se fertilizer had significant effects on titratable acids, soluble protein, soluble sugars and so on in grape berries during the shelf life $(p<0.001)$. 1-MCP had significant effects on soluble proteins, Vc, total soluble solids, titratable acids in grape berries during the shelf life $(p<0.001)$, and the interaction of the two factors had significant effects on all fruit quality except for resveratrol in grape berries $(p<0.001)$ (Table 3$)$.

Table 3. The two-factor interaction analysis between Se fertilizer and 1-MCP of fruit quality in grape berries.

\begin{tabular}{ccccccccc}
\hline & $\begin{array}{c}\text { Soluble } \\
\text { Sugars }\end{array}$ & $\begin{array}{c}\text { Soluble } \\
\text { Proteins }\end{array}$ & $\begin{array}{c}\text { Vitamin } \\
\text { C }\end{array}$ & $\begin{array}{c}\text { Total } \\
\text { Soluble } \\
\text { Solids }\end{array}$ & $\begin{array}{c}\text { Titratable } \\
\text { Acidity }\end{array}$ & Resveratrol & Proanthocyanidin & $\begin{array}{c}\text { Selenium } \\
\text { Content }\end{array}$ \\
\hline $\mathrm{A}$ & $* * *$ & $* * *$ & $* * *$ & $* * *$ & $* * *$ & $* * *$ & $* * *$ & $* * *$ \\
$\mathrm{~B}$ & $* *$ & $* * *$ & $* * *$ & $* * *$ & $* * *$ & NS & $* *$ & $*$ \\
$\mathrm{~A} \times \mathrm{B}$ & $* * *$ & $* * *$ & $* * *$ & $* * *$ & $* * *$ & $* * *$ & $* *$ & $* * *$ \\
\hline
\end{tabular}

Note: A: Se fertilizer; B: 1-MCP; the ${ }^{*},{ }^{* *}$, and ${ }^{* * *}$ significant at $p<0.05,0.01$, and 0.001 levels, respectively; NS-not significant.

\section{Discussion}

\subsection{Effect of Se Fertilizer Application on Se Content in Grape Berries}

Numerous research had indicated that adding Se fertilizer can improve Se concentration of crop edible part effectively, such as rice, wheat and maize $[4,28,29]$, which Se content in rice and wheat grains increased 51 and 10 folds respectively of Se fertilizer application compared to that of control, and it improved Se concentration in corn either soil application or foliar spray significantly. However, the bioavailable of Se in human and animal foodstuffs was strongly affected by the source and application forms of Se fertilizer that supplied to plants [30]. And those studies mostly selected 
the exogenous Se fertilizer as the main forms, including selenite and selenate. Due to the selenite was adsorption onto ferric soil minerals or accumulation in plant tissue, which is not part of human diet, selenite had less bioavailable when it was applied into the soil [31-33]. Therefore, it was considered that Se fertilizer application in soil is disadvantageous for improving the concentration of Se in crops. Furthermore, studies of Premarathna et al. (2010) and Keskinen et al. (2014) shown that over 80\% selenite and selenate application in soil would be leached out or fixed within one week after rainfall or irrigation, it was a wasted Se biofortification method [33,34]. In addition, the excessive selenite or selenate addition inhibited plant growth, it was also resulting in a high mortality rate when applied with 2.5 and $5.0 \mathrm{mg} / \mathrm{kg}$ [35]. Therefore, inorganic Se fertilizer was not a suitable choice for Se fertilizer addition, while foliar Se fertilizer may be more beneficial to improve Se concentrations than soil application. Hence, this research concluded that foliar spray $120 \mathrm{~g} / \mathrm{L}$ of amino acid-chelated Se-enriched foliar fertilizer was contributing to increasing Se concentration in grape berries, also plants absorbed easily, and it had no harm for plants and human. Similarly, Fang et al. (2009) suggested that foliar Se fertilizer could promote the absorption and accumulation of Se content in the edible part of plants [36].

\subsection{Effect of Foliar Se Fertilizer on Fruit Quality at Maturity}

Studies had reported that minerals fertilizer affect fruit quality [37]. Similarly, Se fertilizer as one of the micro-minerals fertilizers significantly affect the quality, such as amino acids, proteins, soluble sugars, Vc in potatoes, onions, rice and green tea leaves [22,38-40]. Researchers had done the similar study of Se fertilizer application on wheat, and it improved the nutrient content of crop including proteins, soluble solids, soluble sugars [41], the results were consistent with our study that foliar spray Se fertilizer improved the content of soluble sugars, TSS, soluble proteins and Vc in grape berries (Table 2). In addition, Se fertilizer application decreased the titratable acidity of grape berries (Table 2), which was also confirmed in kumquat fruit [42], at the same time increased the fruit sugar-acid ratio. Soluble sugars and soluble proteins in grape berries under Se fertilizer treated was higher compared to that of CK, it may be due to the high photosynthetic rate of Se fertilizer application, also it was confirmed in our previous study $[43,44]$, which was focused on changes of sugars content in response to foliar Se fertilizer, the results showed that the high acid invertase of grape berries and the high photosynthetic rate of leaves explained the increasing of soluble sugars in grape berries with foliar spray Se fertilizer. In addition, there were almost no reports about the impact of Se fertilizer on RES and OPC content in grape berries except our previous study [7], so this study was more necessary. All of our studies indicated that foliar spray Se fertilizer had no significant effect on RES content in grape berries, and OPC content under SE treatments was increased obviously compared with CK.

\subsection{Effect of 1-MCP on Fruit Quality During Shelf Life Stages}

During storage and shelf life, the samples with 1-MCP application decreased the ethylene production as had been reported in many fruits [9]. Results of previous studies had indicated that the samples with 1-MCP application did not completely inhibit the production of ethylene, but continued to produce a certain level of ethylene [45], and it is believed that a certain level of ethylene production is necessary for the normal maturation of peaches after refrigeration [46]. As a non-climacteric fruit, the grape berries could not produce ethylene in the process of storage, but the pedicel could continuously produce ethylene. On account of exogenous ethylene $c$ also initiate their ripening and senescence, hence, we could use 1-MCP to delay the changes of fruit quality in table grape during shelf life stages.

1-MCP could improve the contents and profiles of sugars, titratable acidity and amino acids in fruit during storage stages depending on the fruit species, cultivars and the storage conditions, also it sustained higher antioxidant contents in many fruits after storage compared with that of non 1-MCP application [13]. Similarly, in our study, the nutritional components including Se content, titratable acidity, $\mathrm{Vc}$ and $\mathrm{OPC}$ in grape berries under 1-MCP treated was still higher compared to non 1-MCP treated during the whole shelf life stages. 
Although 1-MCP application significantly affects peaches ripening, it does not completely prevent ripening, and it suggested that ethylene receptors were continuously synthesized in the fruit during storage [47]. In our study, the decay number of grapes without 1-MCP application (CK/SE + CK) was higher compared to that of 1-MCP treated (CK/SE + 1-MCP) in both 2016 and 2017, similar result was obtained in Xu et al. (2016) study that 1-MCP reduced the decay incidence and lesion expansion caused by C. gloeosporioides in mango fruits [48]. In addition, in this study, TSS content in grape berries was higher under 1-MCP treated than those not treated during the later shelf life stages, and this effect was consistent with study of Chen and Spotts (2005) that indicated TSS in "d'Anjou" pears under 1-MCP treatment was slightly higher compared to that of unprocessed fruit [49]. Also DeEll and Ehsani-Moghaddam (2017) found TSS content in Bartlett pears was higher with 1-MCP compared to that of CK [10]. Previous study indicated that 1-MCP plays a role in regulating the expression of mature metabolic-related gene and reduce the respiration rate of fruits by reducing titratable acidity [50]. In this study, we concluded that the 1-MCP application inhibited the reducing of titratable acidity in grape berries during shelf life stages. It was agreed with previous reports that the titratable acidity in jackfruit decreased during maturation and aging which was caused by titratable acidity is used as substrate for respiratory metabolism [51,52].

In horticultural crops, Se had potential benefits in terms of shelf life stage, and in fruit, Se might regulate the ripening process through its antioxidant and anti-aging properties, with benefits for commercial life of postharvest and greater benefits for human health [53]. Though in this study, the SE +1 -MCP treatment had the most excellent fruit quality among all treatments during shelf life stages in 2016 and 2017, further investigations were still needed to fully understand the molecular and biochemical mechanisms, by which Se or 1-MCP directly or indirectly affect fruit tissues during the ripening and postharvest stages.

\section{Conclusions}

Spraying Se fertilizer could significantly increase Se content of grape berries at maturity, and the raised rate were $43.09 \%$ and $33.24 \%$ compared to that of control in 2016 and 2017 respectively; also it improved the nutritional components including TSS (the ratio were $6.90 \%$ and $5.27 \%$ in 2016 and 2017 respectively), $\mathrm{Vc}_{\mathrm{c}}$ (the ratio were $9.09 \%$ and $20.00 \%$ in 2016 and 2017 respectively), soluble sugars (the ratio were $8.28 \%$ and $13.38 \%$ in 2016 and 2017 respectively), soluble proteins (the ratio were $22.63 \%$ and $15.33 \%$ in 2016 and 2017 respectively), OPC (the ratio were $62.76 \%$ and $86.74 \%$ in 2016 and 2017 respectively) etc. 1-MCP application could delay the process of ripening and senescence for Se-enriched grape during shelf life stages, and then maintaining the postharvest quality of table grape, it allows us to market the fruit at a more advanced ripening stage without quality loss. Hence, study on the production of Se-enriched grapes with foliar Se fertilizer could address Se deficiencies in humans effectively, and 1-MCP treatment is beneficial for the non-sulfur storage of fresh fruit. In the future perspective, the synergy effect of Se and 1-MCP on fruit quality will be a tread of research.

Author Contributions: Conceptualization, Y.L. and S.Z.; methodology, S.Z.; software, S.Z.; validation, X.A. and H.Y.; formal analysis, L.M.; investigation, S.Z.; resources, Y.L.; data curation, S.Z.; writing-original draft preparation, S.Z.; writing-review and editing, S.Z.; visualization, S.Z.; supervision, X.A.; project administration, Y.L.; funding acquisition, Y.L. and S.Z. All authors have read and agreed to the published version of the manuscript.

Funding: This work was financially supported by the Science and Technology Support Program of Shaanxi province Academy of Science (No. 2014K-03) and National Science and Technology Support Program (No. 2014B AD14B006) and Doctoral Fund of Henan Polytechnic University (B2019-4).

Conflicts of Interest: The authors declare no conflict of interest. The funders had no role in the design of the study; in the collection, analyses, or interpretation of data; in the writing of the manuscript, or in the decision to publish the results. 


\section{References}

1. Locatelli, M.; Travaglia, F.; Coisson, J.D.; Bordiga, M.; Arlorio, M. Phenolic composition of Nebbiolo grape (Vitis vinifera L.) from Piedmont: Characterization during ripening of grapes selected in different geographic areas and comparison with Uva Rara and Vespolina cv. Eur. Food Res. Technol. 2016, 242, 1-12. [CrossRef]

2. Toaldo, I.M.; Fogolari, O.; Pimentel, G.C.; De Gois, J.S.; Borges, D.L.G.; Caliari, V.; Bordignon-Luiz, M.T. Effect of grape seeds on the polyphenol bioactive content and elemental composition by ICP-MS of grape juices from Vitis labrusca L. LWT Food Sci. Technol. 2013, 53, 1-8. [CrossRef]

3. Kisková, T.; Jendželovský, R.; Rentsen, E.; Maier-Salamon, A.; Kokošová, N.; Papčová, Z.; Mikes, J.; Orendáš, P.; Bojkova, B.; Kubatka, P.; et al. Resveratrol enhances the chemopreventive effect of celecoxib in chemically induced breast cancer in rats. Eur. J. Cancer Prev. 2014, 23, 506-513. [CrossRef] [PubMed]

4. Broadley, M.R.; Alcock, J.; Alford, J.; Cartwright, P.; Foot, I.; Fairweather-Tait, S.J.; Hart, D.J.; Hurst, R.; Knott, P.; McGrath, S.P.; et al. Selenium biofortification of high-yielding winter wheat (Triticum aestivum L.) by liquid or granular Se fertilisation. Plant Soil 2010, 332, 5-18. [CrossRef]

5. Fordyce, F.M. Selenium Deficiency and Toxicity in the Environment. In Essentials of Medical Geology; Elsevier: London, UK, 2005.

6. Kuldeep, V.; Yadav, A.L.; Singh, H.K.; Yadav, D.K. Effect of foliar spray of nutrients on fruit drop, yield and quality attributes of mango fruit (Mangifera indica L.) cv-Amrapali. Plant Arch. 2010, 10, 359-360.

7. Zhu, S.M.; Liang, Y.; Gao, D.; An, X.; Kong, F. Spraying foliar selenium fertilizer on quality of table grape (Vitis vinifera L.) from different source varieties. Sci. Hortic. 2017, 218, 87-94. [CrossRef]

8. Crisosto, C.H.; Smilanick, J.L.; Dokoozlian, N.K. Table grapes suffer water loss, stem browning during cooling delays. Calif. Agric. 2001, 55, 39-42. [CrossRef]

9. Watkins, C.B. The use of 1-methylcyclopropene (1-MCP) on fruits and vegetables. Biotechnol. Adv. 2006, 24, 389-409. [CrossRef]

10. DeEll, J.; Moghaddam, B.E. Timing of postharvest 1-methylcyclopropene treatment affects Bartlett pear quality after storage. Can. J. Plant Sci. 2011, 91, 853-858. [CrossRef]

11. Sisler, E.C.; Serek, M. Inhibitors of ethylene responses in plants at the receptor level: Recent developments. Physiol. Plant. 1997, 100, 577-582. [CrossRef]

12. Sisler, E.C.; Serek, M. Compounds Interacting with the Ethylene Receptor in Plants. Plant Biol. 2003, 5, 473-480. [CrossRef]

13. Guan, J.; Hu, M.; Shen, C.; Zhou, S.; Cheng, Y.; He, J. Effects of 1-Methylcyclopropene on Active Composition in Fruits. In Processing and Impact on Active Components in Food; Academic Press: Cambridge, MA, USA, 2015; pp. 133-137, Printed and bound in United States of America.

14. Blankenship, S.M.; Dole, J.M. 1-Methylcyclopropene: A review. Postharvest Biol. Technol. 2003, $28,1-25$. [CrossRef]

15. Kolniak-Ostek, J.; Oszmiański, J.; Rutkowski, K.P.; Wojdyło, A. Effect of 1-methylcyclopropene postharvest treatment apple and storage on the cloudy juices properties. LWT Food Sci. Technol. 2014, 59, 1166-1174. [CrossRef]

16. Zheng, W.-W.; Chun, I.-J.; Hong, S.-B.; Zang, Y.-X. Quality characteristics of fresh-cut 'Fuji' apple slices from 1-methylcyclopropene-, calcium chloride-, and rare earth-treated intact fruits. Sci. Hortic. 2014, 173, 100-105. [CrossRef]

17. Ergun, M.; Jeong, J.; Huber, D.J.; Cantliffe, D.J. Physiology of fresh-cut 'Galia' (Cucumis melo var. reticulatus) from ripe fruit treated with 1-methylcyclopropene. Postharvest Biol. Technol. 2007, 44, 286-292. [CrossRef]

18. Pelayo, C.; Vilas-Boas, E.V.B.; Benichou, M.; Kader, A.A. Variability in responses of partially ripe bananas to 1-methylcyclopropene. Postharvest Biol. Technol. 2003, 28, 75-85. [CrossRef]

19. Vilas-Boas, E.V.D.B.; Kader, A.A. Effect of 1-methylcyclopropene (1-MCP) on softening of fresh-cut kiwifruit, mango and persimmon slices. Postharvest Biol. Technol. 2007, 43, 238-244. [CrossRef]

20. Budu, A.S.; Joyce, D.C. Effect of 1-methylcyclopropene on the quality of minimally processed pineapple fruit. Aust. J. Exp. Agric. 2003, 43, 177-184. [CrossRef]

21. Gago, C.M.; Guerreiro, A.C.; Miguel, G.; Panagopoulos, T.; Sánchez, C.; Antunes, M.D. Effect of harvest date and 1-MCP (SmartfreshTM) treatment on 'Golden Delicious' apple cold storage physiological disorders. Postharvest Biol. Technol. 2015, 110, 77-85. [CrossRef] 
22. Premarathna, L.; McLaughlin, M.J.; Kirby, J.K.; Hettiarachchi, G.M.; Stacey, S.; Chittleborough, D.J. Selenate-Enriched Urea Granules Are a Highly Effective Fertilizer for Selenium Biofortification of Paddy Rice Grain. J. Agric. Food Chem. 2012, 60, 6037-6044. [CrossRef]

23. Kochert, G. Carbohydrate determination by the phenol-sulfuric acid method. Handb. Phycol. Methods 1978, 2, 95-97.

24. Gao, J.F. Experimental Guidance for Plant Physiology; Higer Education Press: Beijing, China, 2006.

25. Bradford, M.M. A rapid method for the quantitation of miicrogram quantities of protein utilizing the principle of protein-dye binding. Anal. Biochem. 1976, 72, 248-254. [CrossRef]

26. Porter, L.J.; Hrstich, L.N.; Chan, B.G. The conversion of procyanidins and prodelphinidins to cyanidin and delphinidin. Phytochemistry 1985, 25, 223-230. [CrossRef]

27. Jiang, S.S.; Liu, Z.F.; Wu, S.P. Fading spectrophotometric determination of resveratrol with potassium permanganate. J. Southwest Univ. 2009, 31, 67-70.

28. Wang, Y.-D.; Wang, X.; Wong, Y.-S. Generation of selenium-enriched rice with enhanced grain yield, selenium content and bioavailability through fertilisation with selenite. Food Chem. 2013, 141, 2385-2393. [CrossRef]

29. Wang, J.; Wang, Z.; Mao, H.; Zhao, H.; Huang, D. Increasing Se concentration in maize grain with soil- or foliar-applied selenite on the Loess Plateau in China. Field Crops Res. 2013, 150, 83-90. [CrossRef]

30. Longchamp, M.; Castrec-Rouelle, M.; Biron, P.; Bariac, T. Variations in the accumulation, localization and rate of metabolization of selenium in mature Zea mays plants supplied with selenite or selenate. Food Chem. 2015, 182, 128-135. [CrossRef]

31. Li, Z.; Man, N.; Wang, S.; Liang, D.-L.; Liu, J. Selenite adsorption and desorption in main Chinese soils with their characteristics and physicochemical properties. J. Soils Sediments 2015, 15, 1150-1158. [CrossRef]

32. Carey, A.-M.; Scheckel, K.G.; Lombi, E.; Newville, M.; Choi, Y.; Norton, G.J.; Price, A.H.; Meharg, A. Grain Accumulation of Selenium Species in Rice (Oryza sativa L.). Environ. Sci. Technol. 2012, 46, 5557-5564. [CrossRef]

33. Keskinen, R.; Räty, M.; Yli-Halla, M. Selenium fractions in selenate-fertilized field soils of Finland. Nutr. Cycl. Agroecosyst. 2011, 91, 17-29. [CrossRef]

34. Premarathna, H.L.; McLaughlin, M.J.; Kirby, J.; Hettiarachchi, G.M.; Beak, D.; Stacey, S.; Chittleborough, D. Potential Availability of Fertilizer Selenium in Field Capacity and Submerged Soils. Soil Sci. Soc. Am. J. 2010, 74, 1589-1596. [CrossRef]

35. Pezzarossa, B.; Remorini, D.; Piccotino, D.; Malagoli, M.; Massai, R. Effects of selenate addition on selenium accumulation and plant growth of two Prunus rootstock genotypes. J. Plant Nutr. Soil Sci. 2009, 172, 261-269. [CrossRef]

36. Fang, Y.; Zhang, Y.; Catron, B.; Chan, Q.; Hu, Q.; Caruso, J.A. Identification of selenium compounds using HPLC-ICPMS and nano-ESI-MS in selenium-enriched rice via foliar application. J. Anal. At. Spectrom. 2009, 24, 1657-1664. [CrossRef]

37. Marzouk, H.; Kassem, H.A. Improving fruit quality, nutritional value and yield of Zaghloul dates by the application of organic and/or mineral fertilizers. Sci. Hortic. 2011, 127, 249-254. [CrossRef]

38. Hu, Q.; Xu, J.; Pang, G. Effect of Selenium on the Yield and Quality of Green Tea Leaves Harvested in Early Spring. J. Agric. Food Chem. 2003, 51, 3379-3381. [CrossRef] [PubMed]

39. Kopsell, D.A.; Randle, W.M. Selenate Concentration Affects Selenium and Sulfur Uptake and Accumulation by 'Granex 33' Onions. J. Am. Soc. Hortic. Sci. 1997, 122, 721-726. [CrossRef]

40. Munshi, C.B.; Combs, G.F.; Mondy, N.I. Effect of selenium on the nitrogenous constituents of the potato. J. Agric. Food Chem. 1990, 38, 2000-2002. [CrossRef]

41. Dhillon, K.S.; Dhillon, S.K. Selenium concentrations of common weeds and agricultural crops grown in the seleniferous soils of northwestern India. Sci. Total Environ. 2009, 407, 6150-6156. [CrossRef]

42. Luo, X.Y.; Wu, B.; Peng, P.; Ren, L.L.; Xia, M.L.; Chen, J.H. Determining and analyzing content of invert sugar and reducing sugar and total sugar and vitamin $\mathrm{C}$ to ganzhou selenium-rich navel oranges. China Food Addit. 2011, 4, 203-208.

43. Zhu, S.M.; Liang, Y.; An, X.; Kong, F.; Gao, D.; Yin, H. Changes in sugar content and related enzyme activities in table grape (Vitis viniferaL.) in response to foliar selenium fertilizer. J. Sci. Food Agric. 2017, 97, 4094-4102. [CrossRef]

44. Yin, N.; Mu, L.; Liang, Y.L.; Hao, W.L.; Yin, H.F.; Zhu, S.M.; An, X.J. Effects of foliar selenium fertilizer on fruit yield, quality and selenium content of three varieties of Vitis vinifera. Chin. J. Appl. Ecol. 2020, 31, 953-958. 
45. Özkaya, O.; Yildirim, D.; Dündar, Ö.; Tükel, S.S. Effects of 1-methylcyclopropene (1-MCP) and modified atmosphere packaging on postharvest storage quality of nectarine fruit. Sci. Hortic. 2016, 198, 454-461. [CrossRef]

46. Dong, L.; Zhou, H.-W.; Sonego, L.; Lers, A.; Lurie, S. Ethylene involvement in the cold storage disorder of 'Flavortop' nectarine. Postharvest Biol. Technol. 2001, 23, 105-115. [CrossRef]

47. Liu, H.; Jiang, W.; Zhou, L.; Wang, B.; Luo, Y. The effects of 1-methylcyclopropene on peach fruit (Prunus persica L. cv. Jiubao) ripening and disease resistance. Int. J. Food Sci. Technol. 2005, 40, 1-7. [CrossRef]

48. Xu, X.; Lei, H.; Ma, X.; Lai, T.; Song, H.; Shi, X.; Li, J. Antifungal activity of 1-methylcyclopropene (1-MCP) against anthracnose (Colletotrichum gloeosporioides) in postharvest mango fruit and its possible mechanisms of action. Int. J. Food Microbiol. 2017, 241, 1-6. [CrossRef] [PubMed]

49. Chen, P.M.; Spotts, R.A. Changes in Ripening Behaviors of 1-MCP-Treated 'd'Anjou' Pears after Storage. Int. J. Fruit Sci. 2005, 5, 3-18. [CrossRef]

50. Tiwari, K.; Paliyath, G. Microarray analysis of ripening-regulated gene expression and its modulation by 1-MCP and hexanal. Plant Physiol. Biochem. 2011, 49, 329-340. [CrossRef]

51. Valero, D.; Díaz-Mula, H.M.; Zapata, P.J.; Guillen, F.; Martínez-Romero, D.; Castillo, S.; Serrano, M. Effects of alginate edible coating on preserving fruit quality in four plum cultivars during postharvest storage. Postharvest Biol. Technol. 2013, 77, 1-6. [CrossRef]

52. Valero, D.; Serrano, M. Postharvest Biology and Technology for Preserving Fruit Quality; CRC Press: Boca Raton, FL, USA, 2010; pp. 45-52.

53. Puccinelli, M.; Malorgio, F.; Pezzarossa, B. Selenium Enrichment of Horticultural Crops. Molecules 2017, 22, 933. [CrossRef]

(C) 2020 by the authors. Licensee MDPI, Basel, Switzerland. This article is an open access article distributed under the terms and conditions of the Creative Commons Attribution (CC BY) license (http://creativecommons.org/licenses/by/4.0/). 